\title{
Genetics Analysis with Down Syndrome and Histopathological Examination of Buccal Epithelial Cells
}

\author{
Análisis Genético y Examen Histopatológico de las Células \\ Epiteliales Bucales en pacientes con Síndrome de Down
}

\author{
S. Kalkanli*; S. Simsek*; M. Balkan*; H. Akbas"; H. Isi"; D. Oral*; A. Turkyılmaz"; M. Fidanboy"; \\ E. Deveci**; O. Baran"*; N. Kalkanli***; M. N. Alp* \& T. Budak*
}

KALKANLI, S.; SIMSEK, S.; BALKAN, M.; AKBAS, H.; ISI, H.; ORAL, D.; TURKYILMAZ, A.; FIDANBOY, M.; DEVECI, E.; BARAN, O.; KALKANLI, N.; ALP, M. N. \& BUDAK, T. Genetics analysis with Down syndrome and histopathological examination of buccal epithelial cells. Int. J. Morphol., 31(2):668-671, 2013.

SUMMARY: Down syndrome is primarily caused by trisomy of chromosome 21 . We reviewed cytogenetic studies performed on 1048 patients who were referred to the Cytogenetics Unit at Dicle University Hospital, Diyarbakir, Southeast Turkey, between 2000 and 2009. The cases were grouped according to the reason of referral for cytogenetic analysis. The highest frequencies of abnormal karyotypes were found among cases that were referred due to suspicion of Down syndrome (84.8\%). For histologic examination to persons with Down syndrome and normal, buccal mucosa smear was prepared by rubbing. Down syndrome are disabled and control groups were compared statistically buccal epithelial cells and nuclei $(\mathrm{p}<0.05)$. Periphery of the nucleus in some patients with Down's syndrome, while the bud structures in the form of micronuclei was observed in the karyolytic cells.

KEY WORDS: Down syndrome; Buccal mucosa; Southeast Turkey; Chromosomal abnormalities; Genetic counseling.

\section{INTRODUCTION}

Down syndrome is reported congenital autosomal anomaly. The overall incidence of Down syndrome worldwide is reported to be $1 / 600$ to $1 / 800$ live births (Gardner \& Sutherland, 2004). Down syndrome is usually caused by an error in cell division called nondisjunction. It is not known why this occurs. There are several reports on the increased incidence of Down syndrome, from different parts of the world, with respect to ethnicity and maternal age (Gardner \& Sutherland; Lamb et al., 2005). In a study of patients with Down syndrome are disabled due to changing age structure of the buccal mucosa micronuclei indicated DNA damage (micronuclei and / or core) cytokinesis defects (binükleer cells or buds), the proliferative potential (basal cell frequency), and / or cell death (condensed chromatin, karyorrhexis, and karyolytic pyknotic cells), such as buccal mucosal epithelium, a number of genetic characteristics discloses defects (Ferreira et al., 2009). The purpose of this study of patients with Down syndrome were identified chromosomal aspects of epithelial cell and nucleus structure of the buccal mucosa of the genetic feature of histopathological review and support.

\section{MATERIAL AND METHOD}

We reviewed cytogenetic studies performed on 1048 patients who were referred to the Cytogenetics Unit at Dicle University Hospital, Diyarbakir, Southeast Turkey, between 2000 and 2009.For routine cytogenetic analysis, $0.3-\mathrm{mL}$ peripheral blood samples were collected from the patients into heparinized test tubes, and then was incubated in complete lymphocyte culture medium in incubator at $37^{\circ} \mathrm{C}$ for 72 h. Metaphases are harvested by adding colcemid for $60 \mathrm{~min}$ followed by hypotonic $\mathrm{KCl}$ treatment for $5 \mathrm{~min}$ and fixation using standard 3:1 methanol-acetic fixative (all reagents were from Gibco Life Technologies Ltd., Paisley, UK).

The karyotype of each patient was determined by Gbanding using trypsin and Giemsa (GTG) (Seabright, 1971) and C-banding using barium (Sumner, 1972) and Giemsa (CBG) (Salamanca \& Armendares, 1974) when necessary. At least 30 cells were routinely analyzed; in cases of mosaicism, this number was increased to approximately 100 metaphases. The best metaphases were photographed to determine the karyotypes. If the case was carrier of a translocation or an inversion or unusual karyotypes, their

\footnotetext{
* Department of Medical Biology and Genetic, Medical Faculty, Dicle University, Diyarbakir, Turkey.

** Department of Histology and Embryology, Medical Faculty,Dicle University, Diyarbakir, Turkey.

*** Department of Dermatology, Medical Faculty, Dicle University, Diyarbakir, Turkey.
} 
parents or other family members were also tested. Translocations not detected by con-ventional light microscopy were submitted to the fluorescence in situ hybridization (FISH) method using whole chromosome painting (WCP) libraries (cytocell for WCP) and a-satellite DNA probes (Samonte et al., 1996), and a minimum of 100 metaphases for each patient were examined. The karyotypic descriptions were reported according to the International System for Human Cytogenetic Nomenclature recommendations (ISCN, 1995). All individuals were informed of the nature of the study, and the signatures of the couples for their informed consent were obtained. All patients interviewed clearly understood that the research was independent of their care, which would not be affected in any way because their participation in the study. No patient declined to participate.

Persons with Down syndrome and normal buccal mucosa smear was prepared by rubbing. Later, preparates that used for oral epithelium were fixed in methanol for 10 minutes stained with Giemsa staining and fixing of flat cells were then observed under Olympus BH2 light microscopy to determine histological changes

Statistical analysis. Data were evaluated as the arithmetic mean \pm standard deviation. Statistics SPSS 11.0 (CHICAGO, ILL., USA) software package using the Mann-Whitney U test was performed. The significance level $\mathrm{p}<0.05$ was considered (Table I).

\section{RESULTS}

A total of 1048 cases were referred for suspected Down syndrome. Of these, 499 had trisomy 21, 32 cases had trisomy 21 with an inversion of chromosome 9 and 24 cases had Robertsonian translocation (Table I) (Balkan et al., 2010).

As a result of Down syndrome and control group, comparative study of cell and nucleus diameters are shown in Table II. The significance level $p<0.05$ was considered. Light microscopic examination of sections with a normal examination of down syndrome; Epithelial cells, oval or circular structure with the normal genetic structure appeared homogenous distribution of the core structure was observed. Basically, the micronuclei were present along with a massive core. Epithelium of the sections obtained from slices of nucleus from a patient with Down syndrome as part of the periphery of the nucleus in the bud-shaped nuclei and micronuclei, sometimes separated, sometimes depending on the observed. In another image of the section of epithelial cell nuclei, and pyknotic nuclei, where karyolytic cell, apoptotic cells were observed. Epithelial cells where some cells were double nuclei with Down syndrome. However, this feature of the core show cytogenetics was the same as one pyknotic, some of the nuclei of epithelial cells were flattened and fusiform structure.

Table I. Cases referred for suspected Down syndrome.

\begin{tabular}{lc}
\hline Results & The number of cases \\
\hline $47, X X,+21$ & 229 \\
$47, X Y,+21$ & 265 \\
$47, X X, \operatorname{inv}(9)(p 13 ; q 13),+21$ & 10 \\
$47, X Y, \operatorname{inv}(9)(p 13 ; q 13),+21$ & 8 \\
$47, X X, \operatorname{inv}(9)(p 12 ; q 13),+21$ & 6 \\
$47, X Y, \operatorname{inv}(9)(p 12 ; q 13),+21$ & 8 \\
$46, X X, \operatorname{der}(14 ; 21)(q 10 ; q 10)$ & 12 \\
$46, X Y, \operatorname{der}(14 ; 21)(q 10 ; q 10)$ & 10 \\
mos 47,XX,+21/46,XX & 2 \\
mos 47,XY,+21/46,XY & 3 \\
46,XX,der(21;21)(q10;q10) & 1 \\
46,XY,der(21;21)(q10;q10) & 1 \\
Total & 555 \\
\hline
\end{tabular}

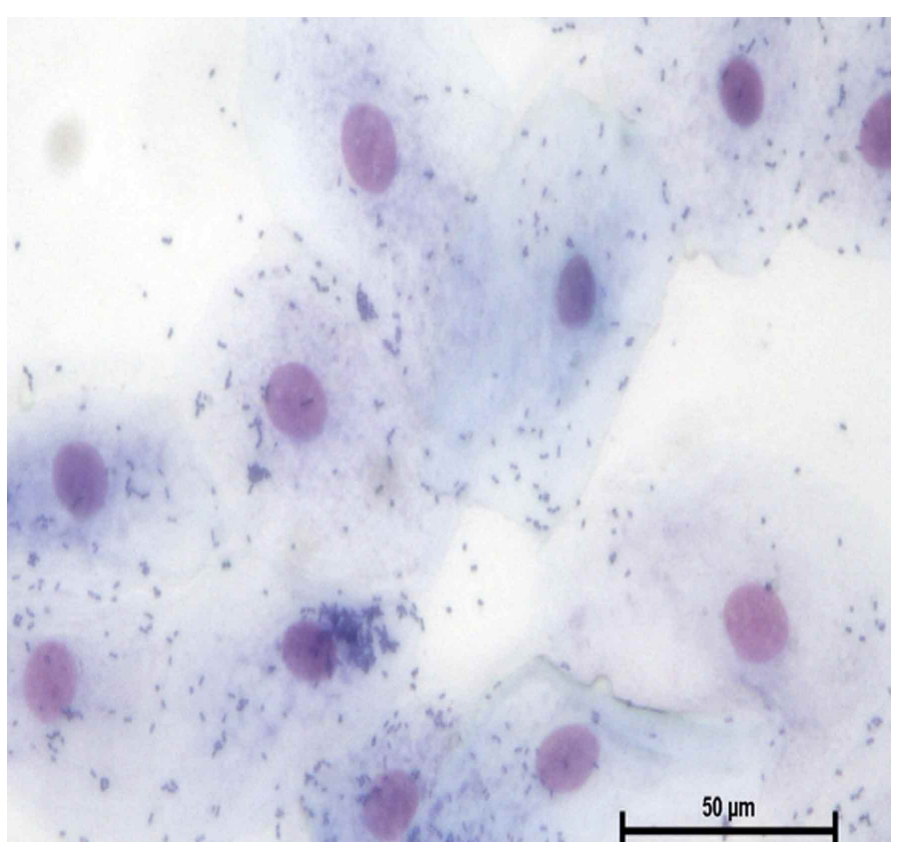

Fig. 1. Appearance of epithelial cells (control group). 


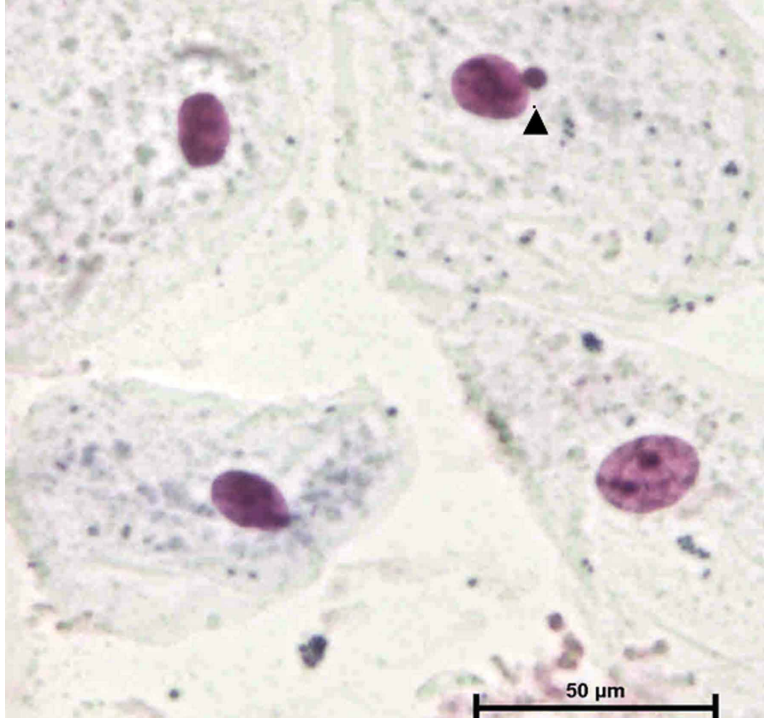

Fig. 2. Nucleus periphery of the micro-nuclear bud (arrow).

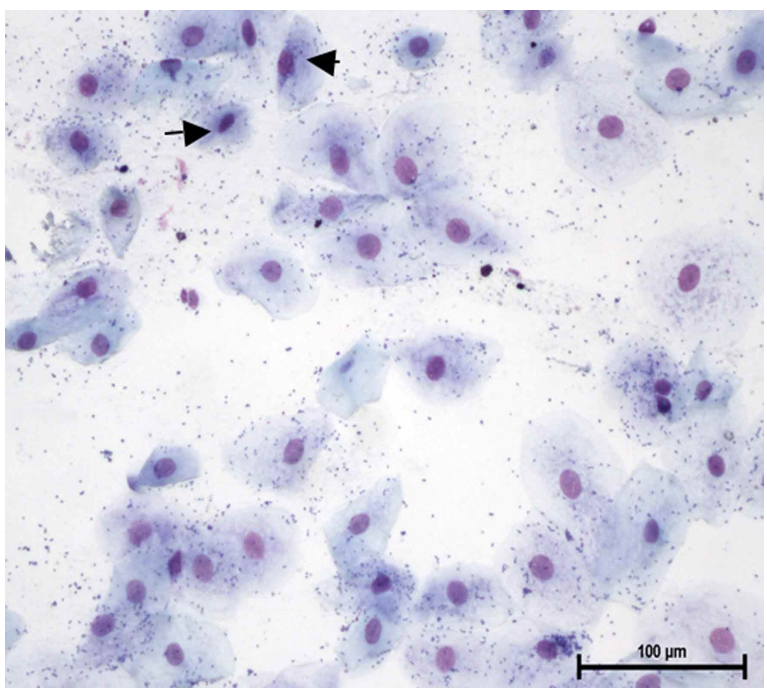

Fig. 3. Flattening of the nucleus of epithelial cells (arrow).

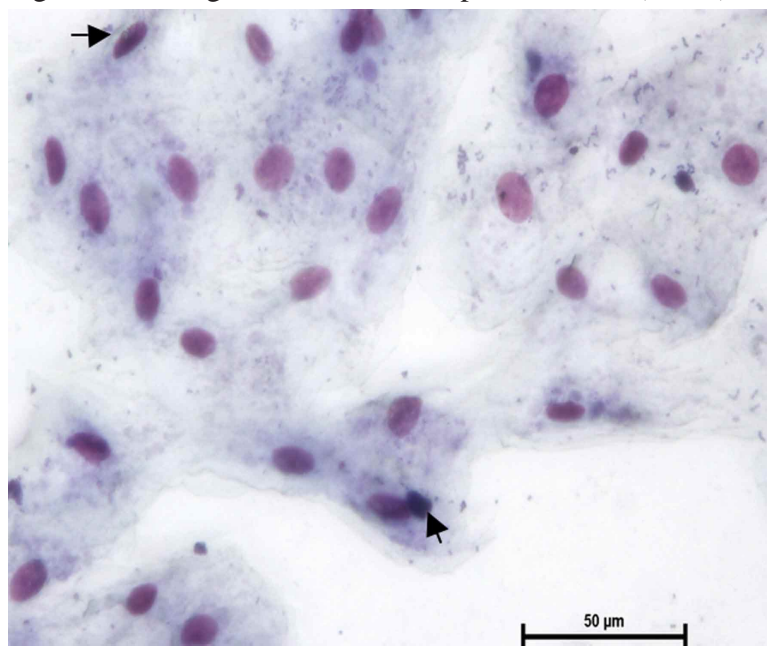

Fig. 4. Degradation of cytogenetic feature of the nucleus (arrow).
Table II. Results of light microscopic examination of buccal frotis in Down syndrome and control groups, comparative study of cell and nucleus diameters.

\begin{tabular}{lccc}
\hline & $\begin{array}{c}\text { Control } \\
(\mathrm{n}=9)\end{array}$ & $\begin{array}{c}\text { patients } \\
\text { with Down's }\end{array}$ & $\mathrm{P}=$ \\
\hline Cell Axis A & $48,70 \pm 0,004$ & $53,06 \pm 6,53$ & 0.046 \\
Cell Axis B & $31,30 \pm 0,19$ & $41,21 \pm 4,67$ & 0.0 \\
$\begin{array}{l}\text { Nucleus } \\
\text { Axis A }\end{array}$ & $7,95 \pm 0,36$ & $9,44 \pm 0,34$ & 0.0 \\
$\begin{array}{l}\text { Nucleus } \\
\text { Axis B }\end{array}$ & $5,40 \pm 0,29$ & $6,59 \pm 065$ & 0,001 \\
\hline
\end{tabular}

\section{DISCUSSION}

The emergence of micro-nuclei, chromosome loss and fragmentation as a result of previous nuclear division stated that an indicator (Fenech \& Morley, 2010). In our study, patients with Down syndrome showed a certain number of cells in epithelial cells of the micro-nucleus structure, Periphery of the nucleus in some patients with Down's syndrome, while the bud structures in the form of micronuclei was observed in the karyolytic cells. Pyknotic nuclei, chromatin fragmentation seen as a result of Karyolytic cell apoptosis in the cells leading to the researcher concluded. Thomas et al. (2008), in their study on epithelial cells of the mucosa of the cheek down syndrome patients have found that a reduction in the number of micronucleus. Reduction of goblet cells in patients with Down syndrome, some investigators diameters, polygonal nucleus and the nucleus is found a pyknotic appearance (Filippello et al., 1997). Down syndrome group has changed as a formal study of epithelial cells and pyknotic nuclei due to impaired chromatin structures were formed. Some of the nuclei of epithelial cells were flattened and fusiform structure, this situation might be due to deterioration of the structure of chromatin. That is evident in this study, the genetic structure of chromosomal and nuclear sizes, and especially in epithelial cells of patients with Down syndrome may occur in the nucleus is made to indicate that DNA damage may occur due to changes in chromatin. As a result we would like to report, patients with Down's syndrome note a formal change in the epithelium nuclei chromatin structure, deterioration of cytogenetic property.

KALKANLI, S.; SIMSEK, S.; BALKAN, M.; AKBAS, H.; ISI, H.; ORAL, D.; TURKYILMAZ, A.; FIDANBOY, M.; DEVECI, E.; BARAN, O.; KALKANLI, N.; ALP, M. N. \& BUDAK, T. Análisis genético y examen histopatológico de las células epiteliales bucales en pacientes con síndrome de Down. Int. J. Morphol., 31(2):662-667, 2013. 
RESUMEN: El síndrome de Down es causado principalmente por la trisomía del cromosoma 21. Se revisaron los estudios citogenéticos realizados en 1.048 pacientes que fueron remitidos a la Unidad de Citogenética del Dicle University Hospital, Diyarbakir, sudeste de Turquía, entre los años 2000 y 2009. Los casos se agruparon de acuerdo a la razón de referencia para el análisis citogenético. Las frecuencias más altas de cariotipos anormales se encontraron ent los casos que fueron remitidos por sospecha de síndrome de Down $(84,8 \%)$. Para el estudio histológico de las personas con y sin síndrome de Down, se realizó el frotis de mucosa oral por hisopado. Los grupos con síndrome de Down y de control (sin síndrome) se compararon estadísticamente en relación a las células epiteliales orales y los núcleos $(\mathrm{p}<0,05)$. Se observaron núcleos periféricos en algunos pacientes con síndrome de Down, mientras que estructuras de tipo brotes en la forma de micronúcleos se observaron en las células cariolíticas.

PALABRAS CLAVE: Síndrome de Down; Mucosa bucal; Sudeste de Turquía; Anomalías cromosómicas; Asesoría genética.

\section{REFERENCES}

Balkan, M.; Akbas, H.; Isi, H.; Oral, D.; Turkyilmaz, A.; Kalkanli, S.; et al. Cytogenetic analysis of 4216 patients referred for suspected chromosomal abnormalities in Southeast Turkey. Genet. Mol. Res., 9(2):1094-103, 2010.

Fenech, M. \& Morley, A. A. Cytokinesis-block micronucleus method in human lymphocytes: effect of in vivo ageing and low dose X-irradiation. Mutat. Res., 161(2):193-8, 1986.

Ferreira, F. L.; Prá, D.; Martino-Roth, M. G. \& Garcias, G. L. Buccal micronucleus frequency is associated with age in Down syndrome. Genet. Mol. Res., 8(4):1231-7, 2009.

Filippello, M.; Cascone, G.; Zagami, A. \& Scimone, G. Impression cytology in Down's syndrome. Br. J. Ophthalmol., 81(8):683$5,1997$.

Gardner, R. J. M. \& Sutherland, G. R. Chromosome Abnormalities and Genetic Counselin. $3^{\text {rd }}$ ed. Oxford, Oxford University Press, 2004.

ISCN (International Software Consulting Network). An International System for Human Cytogenetic Nomenclature. In: Mitelman, F. (Ed.). Recommendations of the International Standing Committee on Human Cytogenetic Nomenclature. Basel, S. Karger Publishers Inc., 1995.

Lamb, N. E.; Yu, K.; Shaffer, J.; Feingold, E. \& Sherman, S. L. Association between maternal age and meiotic recombination for trisomy 21. Am. J. Hum. Genet., 76(1):91-9, 2005.

Salamanca, F. \& Armendares, S. C bands in human metaphase chromosomes treated by barium hydroxide. Ann. Genet., 17(2):135-6, 1974.
Samonte, R. V.; Conte, R. A.; Ramesh, K. H. \& Verma, R. S. Molecular cytogenetic characterization of breakpoints involving pericentric inversions of human chromosome 9. Hum. Genet., 98(5):576-80, 1996.

Seabright, M. A rapid banding technique for human chromosomes. Lancet, 2(7731):971-2, 1971.

Sumner, A. T. A simple technique for demonstrating centromeric heterochromatin. Exp. Cell Res., 75(1):304-6, 1972.

Thomas, P.; Harvey, S.; Gruner, T. \& Fenech, M. The buccal cytome and micronucleus frequency is substantially altered in Down's syndrome and normal ageing compared to young healthy controls. Mutat. Res., 638(1-2):37-47, 2008.

\author{
Correspondence to: \\ Sevgi Kalkanli \\ Department of Medical Biology and Genetic \\ Medical Faculty \\ Dicle University \\ Diyarbakir \\ TURKEY
}

\section{Email: sgkalkanli@yahoo.com kalkanli@dicle.edu.tr}

Received: 17-02-2012

Accepted: 22-10-2012 